\title{
Stock Identification of Critically Endangered Olive Barb, Puntius sarana (Hamilton, 1822) with Emphasis on Management Implications
}

\section{Siddik $\mathbf{M}^{1 *}$, Chaklader $\mathbf{M}^{1}$, Hanif $\mathbf{M}^{1}$, Islam $\mathbf{M}^{2}$, Sharker $\mathbf{M}^{1}$ and Rahman $\mathbf{M}^{3}$}

${ }^{1}$ Department of Fisheries Biology and Genetics, Patuakhali Science and Technology University, Bangladesh ${ }^{2}$ Department of Fisheries Management, Bangladesh Agricultural University, Bangladesh

${ }^{3}$ Department of Fisheries Biology and Genetics, Sheikh Fazilatunnesa Mujib Fisheries College, Bangladesh

\begin{abstract}
The study was carried out to investigate the stock identification of the olive barb, Puntius sarana (Hamilton, 1822) through morphometric characters. A total of 110 sample ranging from $10.00-16.80 \mathrm{~cm}$ in total length (LT) and 13.94-63.46 $\mathrm{g}$ in body weight (BW) were examined to assess the morphometric variation of Puntius sarana from four mighty rivers; the Padma, Meghna, Jamuna and the Halda in Bangladesh. The univariate result showed significantly variation $(p<0.05)$ in seven morphometric characters out of 23 characters among the populations. The discriminant analysis revealed a morphological segregation among the studied populations based on the characters of length of anal base (YZ) and pre-dorsal length (LM). Discriminant function analysis (DFA) showed $55.0 \%$ of the individuals were correctly classified into the four regions on the basis of morphological characters. The first principal component (PC I) analysis elucidated $51.56 \%$ of total variation whereas PC II and PC III were $10.72 \%$ and $8.28 \%$, respectively. The dendrogram was drawn by using morphometric data showed that the Meghna and Halda population make one cluster and the Jamuna and the Padma population form another cluster and the distance between the Padma and Meghna river population were the highest. The canonical graph also revealed all population of the Meghna and Halda were highly overlapped compare to others. The results of the present study would help monitoring the species status in Bangladesh as a bid to take appropriate management measures for its wide geographical distribution.
\end{abstract}

Keywords: Stock structure; Critically endangered; Conservation; Puntius sarana

\section{Introduction}

Bangladesh is endowed with vast fisheries resources having ranked third in Asia after China and India [1,2]. However, the country's huge fisheries resources are dominated by 3 major river systems: the Padma, Jamuna, and Meghna. The Halda is another important river in Bangladesh which is geographically isolated from the 3 major river systems but globally recognized as a maiden breeding ground of freshwater fishes $[3,4]$. There are 260 freshwater fishes in Bangladesh under 145 genera and 55 families, of which 150 species (58\%) have been categorised as small indigenous species (SIS) in Bangladesh [4]. Puntius sarana is an important component of SIS belongs to the family Cyprinidae commonly known as 'Olive barb' is categorized as critically endangered in Bangladesh [5-7] and vulnerable in India according to conservation status [8]. This species is a delicious and nutritious food item in South Asian countries including Bangladesh, Bhutan, India and Nepal due to rich lipoprotein content and soft bony structure $[8,9]$.

Once Puntius sarana was available almost all around the year in ponds, lakes, ditches, floodplains, streams, coastal waters, estuaries, and rivers such as the Padma, Jamuna, Halda, Meghna, and also reported in the Gangetic river system of India and Bangladesh [10,11]. But this species is drastically declined in these water bodies over the years and currently it is on the verge of extinction $[5,6,8]$. There is an ever declining tendency in this fishery in recent years due to apparent deterioration of the habitat, over-exploitation and indeed lack of proper management [12-15]. The increasing water pollution and destruction of breeding grounds for various reasons also restricted the natural breeding of Puntius sarana [11]. In the present situation, it is very crucial to detect the reason of decline and understanding the ecology of the species with a view to managing the species efficiently. As a fishery management tool, morphological characters on fish are crucial from various points of view including evolution, ecology, behavior, conservation, water resource management, and stock assessment and identification [16]. The present study was therefore carried out to identify the stock structure of Puntius sarana in four rivers, the Padma, Jamuna, Meghna and Halda based on morphometric characters in Bangladesh.

\section{Materials and Methods}

\section{Study area and sampling}

A total of 110 samples were collected from the four important rivers in Bangladesh from November, 2013 to September, 2014 (Table 1 and Figure 1). The samples were caught by using the traditional fishing gears like cast net and conical trap. The specimens were moved to the Faculty of Fisheries, Patuakhali Science and Technology University, Bangladesh where all morphometric characteristics were observed following Froese and Pauly [17] method. Digital slide calipers (up to the nearest $0.1 \mathrm{~cm}$ )

\begin{tabular}{|l|c|c|c|c|}
\hline & Population & Collection site (District) & No. of fish & Date of collection \\
\hline 01 & Jamuna river & Sonatala (Bogra) & 29 & 20.11 .13 \\
\hline 02 & Padma river & Pangsha (Rajbari) & 26 & 01.09 .14 \\
\hline 03 & Meghna river & Araihazar (Narayangong) & 30 & 10.09 .14 \\
\hline 04 & Halda river & Hathazari (Chittagong) & 25 & 20.09 .14 \\
\hline
\end{tabular}

Table 1: Sources, number of species and date of collection of Puntius sarana population from four rivers in Bangladesh.

*Corresponding author: Muhammad Abu Bakar Siddik, Department of Fisheries Biology and Genetics, Patuakhali Science and Technology University Patuakhali-8602, Bangladesh, E-mail: siddik@pstu.ac.bd

Received December 12, 2015; Accepted January 20, 2016; Published February 04, 2016

Citation: Siddik M, Chaklader M, Hanif M, Islam M, Sharker M, et al. (2016) Stock Identification of Critically Endangered Olive Barb, Puntius sarana (Hamilton, 1822) with Emphasis on Management Implications. J Aquac Res Development. 7: 411 doi:10.4172/2155-9546.1000411

Copyright: (๑) 2016 Siddik M, et al. This is an open-access article distributed under the terms of the Creative Commons Attribution License, which permits unrestricted use, distribution, and reproduction in any medium, provided the original author and source are credited. 
Citation: Siddik M, Chaklader M, Hanif M, Islam M, Sharker M, et al. (2016) Stock Identification of Critically Endangered Olive Barb, Puntius sarana (Hamilton, 1822) with Emphasis on Management Implications. J Aquac Res Development. 7: 411. doi:10.4172/2155-9546.1000411

Page 2 of 6

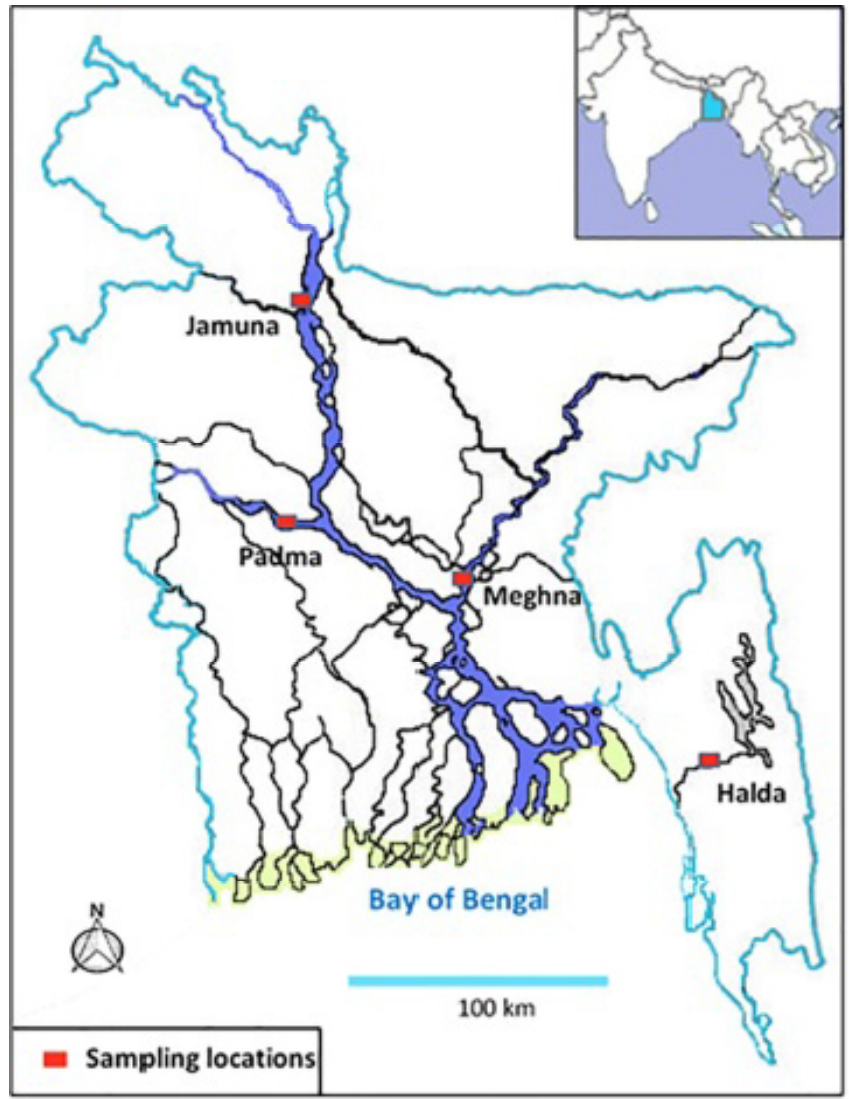

Figure 1: Map of Bangladesh showing the sampling site of four rivers; the Jamuna, Padma, Meghna and Halda.

were used to measure and an electric balance (up to the nearest $0.1 \mathrm{~g}$ ) was used to weigh the specimen.

\section{Statistical analysis}

The morphometric characters of Puntius sarana were analyzed by different statistical methods. Univariate and multivariate statistics were used for analyzing character differences among different sources of samples. Most of the variability in a set of multivariate characters is due to size [18]. Thus, shape analysis should be free from the effect of size to avoid misinterpretation of the results [19]. In order to eliminate any variation resulting from allometric growth, all morphometric measurements were standardized according to Elliott et al. [20].

$$
\mathrm{M}_{\mathrm{adj}}=\mathrm{M}\left(\mathrm{L}_{\mathrm{s}} / \mathrm{L}_{\mathrm{o}}\right)^{\mathrm{b}}
$$

Where,

" $\mathrm{M}$ " is the original morphometric measurement,

" $\mathrm{M}_{\text {adj }}$ " is the size-adjusted measurement,

" $\mathrm{L}_{\mathrm{o}}$ " is the total length of fish, and

" $\mathrm{L}_{\mathrm{s}}$ " is the overall mean of total length for all fish from all samples for each variable.

\section{" $\mathrm{b}$ " is the constant value of the equation}

The parameter $b$ was estimated for each character from the observed data as the slope of the regression of $\log \mathrm{M}$ against $\log$ Lo, using all specimens. Multivariate post hoc Tukey tests were employed to examine the statistical significant differences among mean value of morphometric characters. Discriminant analyses were then applied using stepwise insertion of variables to the size-adjusted traits to test for group membership and to identify discrimination among the populations within the different regions. Then Principal component analysis (PCA) was performed using the same morphological traits because discriminate analysis define the overall morphological variation within the regions [21]. However PCA helps in deduction data dimensions to a few principal components (PC) with identification of meaningful variables based on a combination of the original traits. Varimax rotation was selected for PCA as the rotation minimizes the number of variables with high loading factor. Kaiser [22] recommends that the value of KMO (Kaiser-Meyer-Olkin) less than 0.500 indicates the inadequacy statistic in a PCA for factor analysis. The Wilks' lamda test was performed to compare the differences between and among all groups. Cluster analysis were also applied to determine further the morphometric distances among the individuals of the two groups as a complement to discriminant analysis [23] by adopting the Euclidean distance as a measure of dissimilarity and the UPGMA (unweighted pair group method with arithmetical average) as the clustering algorithm. All statistical analyses were performed using SPSS v16 and SYSTAT v10.

\section{Results}

There were twenty three morphometric characters observed from the samples of four river population of Puntius sarana (Table 2 and Figure 2). Among which the LT, LF, B $\downarrow$, LI, EH, IE, SnL, P $\downarrow, \mathrm{V} \downarrow, \mathrm{A} \downarrow, \mathrm{MN}, \mathrm{WX}$, UZ, UL and UJ didn't show significant variation from each other while the head depth (K) and lowest body depth (B) of the Padma, Meghna and Halda river population revealed significant variation compare to the Jamuna river population. The head length $(\mathrm{LH})$ of Jamuna, Padma

\begin{tabular}{|c|c|c|c|c|}
\hline Characters & Jamuna & Padma & Meghna & Halda \\
\hline $\mathrm{LT}$ & $13.97 \pm 0.31^{a}$ & $13.8 \pm 0.51^{a}$ & $14.89 \pm 0.28^{a}$ & $14.12 \pm 0.39^{a}$ \\
\hline LS & $10.99 \pm 0.28^{\mathrm{ab}}$ & $10.67 \pm 0.40^{b}$ & $11.74 \pm 0.20^{\mathrm{a}}$ & $11.02 \pm 0.38^{\mathrm{ab}}$ \\
\hline LF & $12.24 \pm 0.26^{a}$ & $12.14 \pm 0.44^{a}$ & $13.01 \pm 0.23^{a}$ & $12.33 \pm 0.35^{a}$ \\
\hline $\mathrm{LH}$ & $2.32 \pm 0.06^{b}$ & $2.47 \pm 0.11^{b}$ & $2.83 \pm 0.06^{a}$ & $2.55 \pm 0.08^{b}$ \\
\hline$K_{\downarrow}$ & $2.88 \pm 0.20^{a}$ & $2.27 \pm 0.10^{b}$ & $2.47 \pm 0.09^{b}$ & $2.27 \pm 0.07^{b}$ \\
\hline$M_{\downarrow}$ & $4.21 \pm 0.10^{\mathrm{a}}$ & $4.01 \pm 0.22^{\mathrm{a}}$ & $4.31 \pm 0.15^{\mathrm{a}}$ & $4.10 \pm 0.12^{\mathrm{a}}$ \\
\hline$B$ & $1.68 \pm 0.05^{\mathrm{ab}}$ & $1.52 \pm 0.06^{b}$ & $1.77 \pm 0.08^{a}$ & $1.61 \pm 0.06^{\mathrm{ab}}$ \\
\hline $\mathrm{LI}$ & $0.52 \pm 0.02^{\mathrm{a}}$ & $0.50 \pm 0.01^{a}$ & $0.55 \pm 0.02^{\mathrm{a}}$ & $0.54 \pm 0.01^{a}$ \\
\hline $\mathrm{EH}$ & $1.25 \pm 0.05^{\mathrm{a}}$ & $1.22 \pm 0.05^{a}$ & $1.32 \pm 0.06^{\mathrm{a}}$ & $1.23 \pm 0.02^{\mathrm{a}}$ \\
\hline IE & $0.73 \pm 0.02^{\mathrm{a}}$ & $0.72 \pm 0.04^{a}$ & $0.77 \pm 0.06^{a}$ & $0.70 \pm 0.01^{a}$ \\
\hline SnL & $0.85 \pm 0.04^{a}$ & $0.78 \pm 0.03^{a}$ & $0.79 \pm 0.03^{a}$ & $0.78 \pm 0.02^{\mathrm{a}}$ \\
\hline LM & $5.32 \pm 0.10^{\mathrm{b}}$ & $5.25 \pm 0.25^{b}$ & $5.85 \pm 0.12^{\mathrm{a}}$ & $5.39 \pm 0.15^{\mathrm{ab}}$ \\
\hline NS & $3.87 \pm 0.09^{a}$ & $3.45 \pm 0.15^{b}$ & $3.44 \pm 0.18^{b}$ & $3.31 \pm 0.14^{b}$ \\
\hline$D_{1}$ & $2.31 \pm 0.07^{b}$ & $2.43 \pm 0.08^{b}$ & $2.69 \pm 0.08^{a}$ & $2.54 \pm 0.09^{a b}$ \\
\hline$P_{\downarrow}$ & $2.18 \pm 0.08^{a}$ & $2.12 \pm 0.08^{a}$ & $2.25 \pm 0.06^{a}$ & $2.07 \pm 0.08^{a}$ \\
\hline$V_{\downarrow}$ & $1.93 \pm 0.06^{\mathrm{a}}$ & $1.83 \pm 0.07^{\mathrm{a}}$ & $1.95 \pm 0.05^{\mathrm{a}}$ & $1.85 \pm 0.07^{\mathrm{a}}$ \\
\hline$A_{\downarrow}$ & $1.67 \pm 0.06^{a}$ & $1.69 \pm 0.07^{a}$ & $1.79 \pm 0.09^{a}$ & $1.69 \pm 0.05^{\mathrm{a}}$ \\
\hline $\mathrm{MN}$ & $1.88 \pm 0.07^{a}$ & $1.77 \pm 0.07^{a}$ & $1.96 \pm 0.06^{a}$ & $1.76 \pm 0.08^{\mathrm{a}}$ \\
\hline QR & $0.46 \pm 0.04^{b}$ & $0.53 \pm 0.02^{\mathrm{a}}$ & $0.59 \pm 0.02^{\mathrm{a}}$ & $0.56 \pm 0.02^{\mathrm{a}}$ \\
\hline$W X$ & $0.59 \pm 0.02^{\mathrm{a}}$ & $0.61 \pm 0.02^{\mathrm{a}}$ & $0.61 \pm 0.08^{a}$ & $0.59 \pm 0.03^{a}$ \\
\hline $\mathrm{YZ}$ & $1.17 \pm 0.05^{\mathrm{a}}$ & $1.07 \pm 0.06 a$ & $1.21 \pm 0.06^{\mathrm{a}}$ & $1.18 \pm 03^{\mathrm{a}}$ \\
\hline $\mathrm{JL}$ & $0.91 \pm 0.02^{\mathrm{a}}$ & $0.81 \pm 0.04^{\mathrm{a}}$ & $0.81 \pm 0.04^{a}$ & $0.76 \pm 0.03^{a}$ \\
\hline JU & $0.77 \pm 0.03^{a}$ & $0.73 \pm 0.03^{a}$ & $0.70 \pm 0.03^{a}$ & $0.66 \pm 0.03^{a}$ \\
\hline
\end{tabular}

Values are mean \pm standard error. Mean values in each row bearing different superscripts are significantly different $(P<0.05)$.

Table 2: Morphometric characters of Puntius sarana population observed in the Jamuna, Padma, Meghna and Halda rivers of Bangladesh. 
Citation: Siddik M, Chaklader M, Hanif M, Islam M, Sharker M, et al. (2016) Stock Identification of Critically Endangered Olive Barb, Puntius sarana (Hamilton, 1822) with Emphasis on Management Implications. J Aquac Res Development. 7: 411. doi:10.4172/2155-9546.1000411

Page 3 of 6

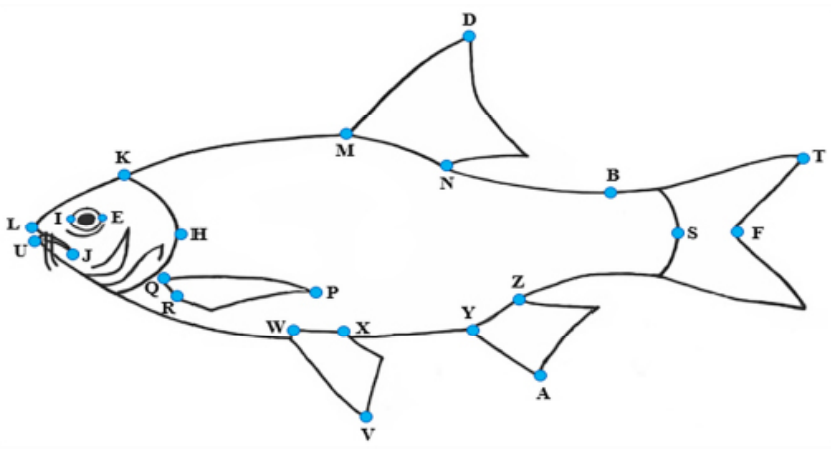

Figure 2: Morphometric measurements of Puntius sarana. Total length (LT); Fork length (LF); Standard length (LS); Head length (LH); Head depth (K $\mathrm{K}_{\downarrow}$ ); Highest body depth $\left(\mathrm{M}_{\downarrow}\right)$; Lowest body depth $\left(\mathrm{B}_{\downarrow}\right)$; Pre-orbital length (LI); Postorbital length (EH); Eye diameter (IE); Pre-dorsal length (LM); Post-dorsal length (NS); Height of dorsal fin (D); Height of pectoral fin (P); Height of ventral fin (V); Height of anal fin (A); Length of dorsal base (MN); Length of pectoral base (QR); Length of ventral base (WX); Length of anal base (YZ); Upper jaw length (JL); Lower jaw length (JU).

and Halda river population showed significant variation than Meghna river population. During multivariate analysis, an inadequate sample size is a common problem with many fish morphology studies [24]. Many authors performed theoretical works for decades on PCA and DFA recommended that the ratio of $\mathrm{N}$ : $\mathrm{P}$ ( $\mathrm{N}$-number of organisms measured and P-parameters included in the analysis) should be at least 3-3.5 [25]. In the present study, 7 characters were retained and the N:P ratio was 8.57 for all 7 morphometric measurements under these circumstance, suggesting adequate sample size for this study. The contributions of the variables to principle components (PC) were examined to determine the most effective morphometric measurement that discriminates the populations. Bartlett's Test of sphericity and the Kaiser-Meyer-Olkin (KMO) measure was executed to observe the fitness of the data for PCA. Generally the KMO statistics fluctuates between 0 and 1 [24] but Kaiser [22] recommends that values greater than 0.5 are acceptable. The value of KMO between 0.5 and 0.7 are mediocre, between 0.7 and 0.8 are good, and between 0.8 and 0.9 are superb [26]. In this study, the obtained value of KMO for the overall matrix is 0.83 and the Bartlett's Test of sphericity is significant $(\mathrm{P}<0.01)$. The results (KMO and Bartlett's) estimated from the present study suggest that the sampled data are appropriate to proceed with a factor analysis procedure.

Principal component analysis of 23 morphometric measurements extracted three factors with eigen-values $>1$, explaining $70.57 \%$ of the variance (Figure 3). The first principal component (PC1) accounted for $51.56 \%$ of the variation, second (PC2), third (PC3) for $10.72 \%$ and $8.28 \%$ respectively. The most significant loadings on PC1 were LT, LF, LS, LH, $\mathrm{K} \downarrow \mathrm{M} \downarrow \mathrm{B} \downarrow$ LI, EH, IE, SnL, LM and NS JL were on PC II and EH, IE, SnL were on PC III, respectively. Nimalathasan [27] worthy mentioned that factor loading greater than 0.30 is considered significant, 0.40 more important, and 0.50 or greater is very significant. For parsimony, only those factors were considered significant in this study having loadings above 0.50. Visual examination of plots of PC I, PC II and PC III scores showed the most similar loadings were $\mathrm{YZ}, \mathrm{P} \downarrow, \mathrm{B} \downarrow \mathrm{M} \downarrow, \mathrm{V} \downarrow \mathrm{LT}, \mathrm{LF}, \mathrm{LH}$, LS, WX, and LM (Figure 3).

Different proportions of morphometric characteristics (LT:LS, $\mathrm{M} \downarrow: \mathrm{B} \downarrow, \mathrm{LH}: \mathrm{IE}, \mathrm{LT}: \mathrm{M} \downarrow, \mathrm{LT}: \mathrm{B} \downarrow, \mathrm{LT}: \mathrm{LH}, \mathrm{LS}: \mathrm{LH})$ of Puntius sarana are given in Table 3 . There was no significant difference $(p>0.05)$ observed in the ratio of $M \downarrow: B \downarrow$ and LT: $\mathrm{M} \downarrow$ through all four river populations

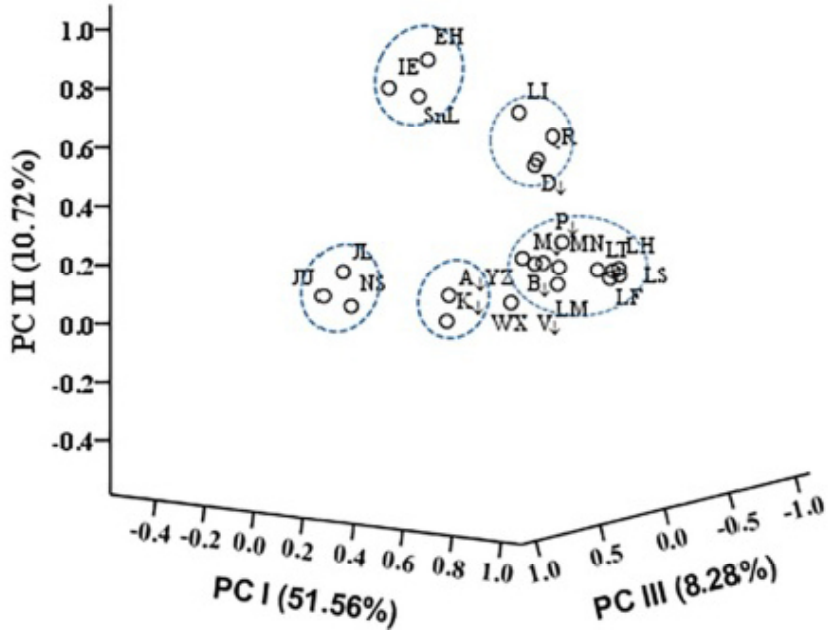

Figure 3: Principal component analysis (PCA) for 23 morphometric characters of Puntius sarana collected from four rivers, Bangladesh.

\begin{tabular}{|l|c|c|c|c|c|c|c|}
\hline Group & LT:LS & $\mathbf{M}_{\downarrow}: \mathbf{B}_{\downarrow}$ & LH:IE & LT: $\mathbf{M}$ & LT: $^{\mathbf{b}}$ & TL:LH & LS:LH \\
\hline Jamuna river & $1.27^{\mathrm{ab}}$ & $2.33^{\mathrm{a}}$ & $3.23^{\mathrm{b}}$ & $3.32^{\mathrm{a}}$ & $8.37^{\mathrm{b}}$ & $6.06^{\mathrm{a}}$ & $4.76^{\mathrm{a}}$ \\
\hline Padma river & $1.29^{\mathrm{a}}$ & $2.15^{\mathrm{a}}$ & $3.51^{\mathrm{ab}}$ & $3.52^{\mathrm{a}}$ & $9.12^{\mathrm{a}}$ & $5.62^{\mathrm{b}}$ & $4.34^{\mathrm{b}}$ \\
\hline Meghna river & $1.28^{\mathrm{b}}$ & $2.43^{\mathrm{a}}$ & $3.89^{\mathrm{a}}$ & $3.48^{\mathrm{a}}$ & $8.58^{\mathrm{ab}}$ & $5.27^{\mathrm{c}}$ & $4.16^{\mathrm{b}}$ \\
\hline Halda river & $1.29^{\mathrm{ab}}$ & $2.32^{\mathrm{a}}$ & $3.65^{\mathrm{ab}}$ & $3.45^{\mathrm{a}}$ & $8.83^{\mathrm{ab}}$ & $5.56^{\mathrm{bc}}$ & $4.33^{\mathrm{b}}$ \\
\hline
\end{tabular}

Vertically, letters $a, b$ and $c$ show statistically significant differences $(p<0.05)$ among the rivers.

Table 3: Different morphometric proportions of Puntius sarana population on four rivers of Bangladesh.

while the ratio of standard length and head length (LS:LH) of Jamuna population was significantly higher $(p<0.05)$ than other three river populations (Table 3). Univariate statistics (ANOVA) revealed that 7

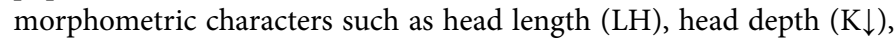
lowest body depth (B $\downarrow$ ), post dorsal length (EH), height of dorsal fin $(\mathrm{D} \downarrow)$, length of pectoral base (QR) and upper jaw length (UL) of 23 morphometric measurements significantly differed to varying degrees $(p<0.05, \mathrm{p}<0.01$ or $\mathrm{P}<0.001)$ among samples (Table 4$)$.

A dendrogram was drawn for all population in four rivers based on morphometric characteristics (Figure 4). The Meghna river populations were nearest to Halda river population compare to two others (Jamuna and Halda) and the Jamuna river population were more adjacent to Padma river population than others (Meghna and Halda ) according to the distance of Squared Euclidean Dissimilarity.

Three discriminate function (DF1, DF2 and DF3) produced based on morphometric characters during the analysis of discriminant function. The DF1 was accounted for $83.2 \%$, the DF2 was accounted for $12 \%$ and the DF3 was accounted for $4.8 \%$ of among groups variability,
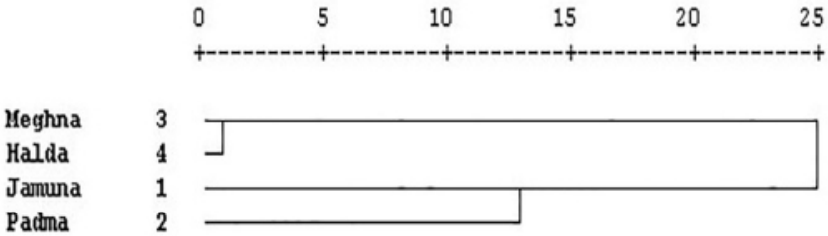

Figure 4: Dendrogram based on morphometric characters of Puntius sarana collected from four rivers, Bangladesh. 


\begin{tabular}{|c|c|c|c|c|c|}
\hline Characters & Wilks' Lambda & $\mathbf{F}$ & df1 & df2 & Sig. \\
\hline LT & 0.92 & 1.55 & 3 & 56 & 0.211 \\
\hline LS & 0.91 & 1.95 & 3 & 56 & 0.131 \\
\hline LF & 0.93 & 1.39 & 3 & 56 & 0.255 \\
\hline $\mathrm{LH}$ & 0.73 & 7.00 & 3 & 56 & $0.000^{* * *}$ \\
\hline $\mathrm{K}_{\downarrow}$ & 0.78 & 5.13 & 3 & 56 & $0.003^{* *}$ \\
\hline $\mathrm{M}_{\downarrow}$ & 0.96 & 0.73 & 3 & 56 & 0.537 \\
\hline $\mathrm{B}_{\downarrow}$ & 0.87 & 2.83 & 3 & 56 & $0.047^{*}$ \\
\hline LI & 0.91 & 1.78 & 3 & 56 & 0.162 \\
\hline $\mathrm{EH}$ & 0.96 & 0.83 & 3 & 56 & 0.483 \\
\hline IE & 0.97 & 0.64 & 3 & 56 & 0.592 \\
\hline SnL & 0.94 & 1.15 & 3 & 56 & 0.335 \\
\hline LM & 0.87 & 2.72 & 3 & 56 & 0.053 \\
\hline NS & 0.87 & 2.86 & 3 & 56 & $0.045^{*}$ \\
\hline $\mathrm{D}_{\downarrow}$ & 0.81 & 4.15 & 3 & 56 & $0.010^{*}$ \\
\hline$P_{\downarrow}$ & 0.94 & 1.12 & 3 & 56 & 0.350 \\
\hline $\mathrm{V}_{\downarrow}$ & 0.95 & 0.99 & 3 & 56 & 0.401 \\
\hline$A_{\downarrow}$ & 0.97 & 0.57 & 3 & 56 & 0.637 \\
\hline $\mathrm{MN}$ & 0.90 & 2.01 & 3 & 56 & 0.123 \\
\hline QR & 0.78 & 5.18 & 3 & 56 & $0.003^{\star *}$ \\
\hline$W X$ & 0.99 & 0.28 & 3 & 56 & 0.844 \\
\hline $\mathrm{YZ}$ & 0.92 & 1.62 & 3 & 56 & 0.195 \\
\hline $\mathrm{JL}$ & 0.84 & 3.47 & 3 & 56 & $0.022^{*}$ \\
\hline JU & 0.89 & 2.33 & 3 & 56 & 0.084 \\
\hline
\end{tabular}

Table 4: Univariate statistics (ANOVA) of morphometric characters of Puntius sarana observed in four river of Bangladesh.

explaining $100 \%$ of total among group variability as per morphometric measurements. The original grouped case classification in the discriminate function analysis have a high degree of correct classification with $55.0 \%$ of all fish being assigned to the correct population. Wilk's lamda tests of discriminant analysis indicated significant differences in first function (Wilk's lambda $=0.411, \chi^{2}=49.77$, d.f. $=6, \mathrm{P}<0.001$ ) of morphometric characters of all populations except the second function (Wilk's lambda $=0.897, \chi^{2}=6.06$, d.f. $=2, \mathrm{P}>0.05$ ), which were nonsignificant. There was some intermingling relationship found among all populations and the populations were not separated. The diagram depicts that Meghna were highly dispersed in their morphological parameter compare to other groups of Jamuna, Padma and Halda. The Meghna and Halda river populations were highly overlapped than the Padma and Jamuna river population (Figure 5). The canonical graph for four river populations which was sequentially distributed in cluster form around their centroid value. This recommends that morphological growth trend of them more or less similar.

\section{Discussion}

The Puntius sarana is one of the most commercially important barb species having great potential for aquaculture not only in Bangladesh but all Southeast Asian countries as well $[8,9]$. In the recent years, there has been a growing concern about the conservation and sustainable management of this species. Therefore, study on basic biological aspects of Puntius sarana is crucial to impose adequate regulations for sustainable fishery management and conservation for this species. In the present study, the morphometric characters of all river population were somewhat similar but some significant variations were observed in HD, HBD, HL (Table 2). A similar study was conducted by Saroniya et al. [28] for different Puntius sp and found variation in HD, HBD among all populations of this species. These variation may have been due to the geography, ecology, human activities, genetic diversity and

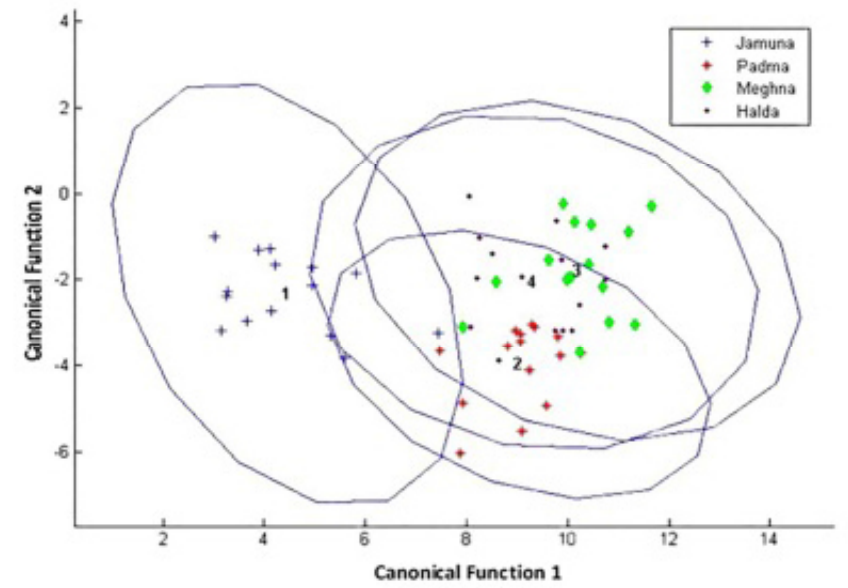

Figure 5: Coordinate plot of two discriminant functions from morphometric measurement of the four river populations of Puntius sarana. Samples referred to 1-Jamuna river, 2-Padma river, 3-Meghna river and 4-Halda river population.

experimental error of the population. There are also several studies have conducted on morphometric measurements and meristic counts on different fishes and found variations due to the geography, ecology and human activities [29-31]. However, morphometric variation of all river populations are expected because the specimens were collected from geographically separated location, may have originated from different ancestors and may be due to their adaptation capacity. Fish are very sensitive to environmental changes and adapt quickly by modifying their physiology and behavior to environmental changes [32]. Environmental changes (such as food abundance and temperature) directly affect the fish and the fish quickly change necessary morphometric in order to adapt themselves $[19,24,32]$. The total length and standard length of Puntius sarana populations were 1.27, 3.3-3.5, 8.3-9.1, 5.5-6.0 and 4.2-4.7 times respectively higher than SL, HBD, LBD and HL; and the highest body depth was 2.4-2.6 times higher than the lowest body depth. Again, the head length was 3.2-3.7 times higher than the eye diameter. A similar type of study was conducted by Hossain et al. [11] found that the total length was 5.5-6.0 and 4.0-5.0 times higher than head length and high body depth, respectively for Puntius pangasius populations. Moreover, the present findings agree with those of Schreck and Moyle [33] and Kurata [34] who reported that environmental factors (water temperature, $\mathrm{pH}$ etc.) considerably affect the morphology of fishes.

The dendrogram which are used in this study resulted in 2 clusters: the Meghna and Halda stocks in one and the Jamuna and Padma stock in another (Figure 4). The Meghna river population had high nearness with Meghna and the Jamuna river with Padma river. This similarity may be due to same genetic structure, environmental and geographical location. Considering DF1, the Jamuna population exhibited some similar characteristics among the Padma, Meghna and Halda river population. The Meghna and Halda river population are broadly overlapped, while the Payra river population clearly differed based on the DF2. In the present investigation, 55.0\% of individuals were correctly classified into their respective groups by DFA, indicating intermingling among some the populations. DFA was applied by Turan et al. [35] on the anchovy (Engraulis encrasicolus) from different areas of the Mediterranean Sea, and found significant heterogeneity among different populations based on morphometric characters. Chaklader et al. [30] applied DFA for three populations of Polynemus paradiseus from the three coastal rivers and reported that environmental parameters 
Citation: Siddik M, Chaklader M, Hanif M, Islam M, Sharker M, et al. (2016) Stock Identification of Critically Endangered Olive Barb, Puntius sarana (Hamilton, 1822) with Emphasis on Management Implications. J Aquac Res Development. 7: 411. doi:10.4172/2155-9546.1000411

and local migration of the fish were influenced the morphological discrimination among them.

The DFA segregation was partly confirmed by PCA, where the graphs of PCA scores for each sample revealed that, among four populations, some features showed overlapping and others were clearly distinct. Among five groups, one group revealed similar loadings of $\mathrm{YZ}, \mathrm{P} \downarrow, \mathrm{B} \downarrow \mathrm{M} \downarrow, \mathrm{V} \mathrm{LT}, \mathrm{LF}, \mathrm{LH}, \mathrm{LS}, \mathrm{WX}, \mathrm{LM}$ in four river population (Figure 3), indicated that these may be contributed by geographical location and environmental condition. Hossain et al. [36] applied PCA on Labeo calbasu collected from the Jamuna and Halda rivers as well as a hatchery, reported environmental factors and local migration of the fish attributing the morphological discrimination of fish.

\section{Conclusion}

The results indicated that Puntius sarana still has morphometric heterogeneity among the population from four different rivers of Bangladesh. The observation given in the present study can further be confirmed based on molecular and biochemical methods. The present study contributes baseline biological information that is expected to be helpful in facilitating the development of management strategies in relation to the fishery and conservation of Puntius sarana populations in selected rivers. In order to ameliorate the current situation and sustain the fishery stock of Puntius sarana in the selected four rivers, it is recommended to:

- Adopt separate management strategies to sustain the stocks from year after year.

- Reduce exploitation rates by implementing appropriate mesh size and gear selectivity to catch the optimum length which gives the maximum possible yield.

- Provide appropriate amenities to allow young individuals to reach the marketable size.

- Implement fisheries and conservation act, imposition ban on breeding time of fish species to sustain this resource for the future use.

\section{References}

1. Hussain M, Mazid M (2001) Genetic improvement and conservation of carp species in Bangladesh. Mymensingh, Bangladesh: BFRI and Penang, Malaysia.

2. Sharker M, Mahmud S, Siddik M, Alam M, Alam M, et al. (2015) Livelihood status of Hilsha fishers around Mohipur Fish Landing site, Bangladesh. World J Fish \& Marine Sci 7: 77-81.

3. Sharker M, Siddik M, Nahar A, Shahjahan M, Faroque A, et al (2015) Genetic differentiation of wild and hatchery populations of Indian major carp Cirrhinus cirrhosis in Bangladesh. J Env Biol 36: 1223-1227.

4. Talwar P, Jhingran A (1991) Inland fishes of India and adjacent countries, India.

5. IUCN (2010) Red book of threatened fishes of Bangladesh, IUCN- The world conservation union 116.

6. Hanif M, Siddik M, Chaklader M, Mahmud S, Nahar A, et al. (2015) Biodiversity and conservation of threatened freshwater fishes in Sandha River, South West Bangladesh. World Applied Sciences Journal 33: 1497-1510.

7. Hanif M, Siddik M, Chaklader M (2015) Fish diversity in the southern coastal waters of Bangladesh: present status, threats and conservation perspectives. Croatian Journal of Fisheries 73: 251-274

8. Siddik M, Nahar A, Ahamed F, Masood Z, Hossain M, et al. (2013) Conservation of Critically Endangered Olive Barb Puntius sarana (Hamilton, 1822) through Artificial Propagation. Our nature 11: 96-104.

9. Chakraborty B, Miah M, Mirza M, Habib M (2005) Growth, yield and returns to Puntius sarana (Hamilton, 1822) Sarpunti, in Bangladesh under Semi-intensive Aquaculture. Asian Fish Sci 18: 307-322.
10. Siddik M, Hanif M, Chaklader M, Nahar A, Mahmud S (2016) Fishery biology of gangetic whiting Sillaginopsis panijus (Hamilton, 1822) endemic to Ganges delta, Bangladesh. Egypt J Aquac Res 41: 307-313.

11. Hossain M, Ohtomi J, Ahmed Z (2009) Morphometric, meristic characteristics and conservation of the threatened fish, Puntius sarana (Hamilton, 1822) (Cyprinidae) in the Ganges River, northwestern Bangladesh. Turk J Fish Aquat Sci 9: 25-27.

12. Khan M, Miyan K, Khan S (2013) Morphometric variation of snakehead fish, Channa punctatus, populations from three Indian rivers. J Appl Ichthyol 29 . 637- 642 .

13. Mir F, Mir J, Chandra S (2013) Phenotypic variation in the Snow trout Schizothoraxri chardsonii (Gray, 1832) (Actinopterygii: Cypriniformes: Cyprinidae) from the Indian Himalayas. Contributions to Zool 82: 115-122.

14. Chaklader M, Nahar A, Siddik M, Sharker R (2014) Feeding habits and diet composition of Asian Catfish Mystus vittatus (Bloch, 1794) in shallow water of an impacted coastal habitat. World J Fish \& Marine Sci 6: 551-556.

15. Nahar A, Siddik M, Alam M, Chaklader M (2015) Population genetic structure of paradise threadfin Polynemus paradiseus (Linnaeus, 1758) revealed by allozyme marker. Intl J Zool Res 11: 48-56.

16. AnvariFar $\mathrm{H}$, Khyabani $\mathrm{A}$, Farahmand $\mathrm{H}$, Vatandoust $\mathrm{S}$, Jahageerdar $\mathrm{S}$ et a (2011) Detection of morphometric differentiation between isolated up- and downstream populations of Siah Mahi (Capoeta capoeta gracilis) (Pisces: Cyprinidae) in the Tajan River (Iran). Hydrobiol 673: 41-52.

17. Froese R, Pauly D (2007) Fishbase 2007. World Wide Web electronic publication. Available at: Junguera S, Perez-Gandaras G (1993) Population diversity in Bay of Biscay anchovy, Engraulisen crasicolus (L., 1785) as revealed by multivariate analysis of morphometric and meristic characters. ICES J Mar Sci 50: 383-391.

18. Strauss R (1985) Evolutionary allometry and variation in body form in the South American catfish genus Corydoras (Callichthyidae). Systematic Biology 34 381-396.

19. Elliott N, Haskard K, Koslow J (1995) Morphometric analysis of orange roughy Hoplostethus atlanticus of the continental slope of southern Australia. Journal of Fish Biology 46: 202-220.

20. Solem O, Berg K (2011) Morphological differences in parr of Atlantic salmon Salmo salar from three regions in Norway. J Fish Biol 78: 1451-1469.

21. Kaiser H (1974) An Index of Factorial Simplicity. Psychometrika 39: 31-36

22. Veasey E, Schammass A, Vencovsky R, Martins S, Bandel G, et al (2001) Germplasm characterization of Sesbania accessions based on multivariate analyses. Genet Resour Crop Evol 48: 79-90.

23. Mir I, Sarkar K, Dwivedi K, Gusain P, Jena K et al (2013) Stock structure analysis of Labeo rohita (Hamilton, 1822) across the Ganga basin (India) using a truss network system. J Appl Ichthyol 29: 1097-1103.

24. Kocovsky M, Adams V, Bronte C (2009) The effect of sample size on the stability of principal component analysis of truss-based fish morphometrics. Trans Am Fish. Soc 138: 487-496.

25. Field A (2000) Discovering statistics using SPSS for Windows. Sage, London.

26. Nimalathasan B (2009) Determinants of key performance indicators (KPIs) of private sector banks in Sri Lanka: an application of exploratory factor analysis. Ann. Stefan cel Mare Univ. Suceava Fac Econ Publ Admin 9: 9-17.

27. Saroniya K, Saksena N, Nagpure S (2013) The morphometric and meristic analysis of some puntius species from central India. Biolife 1: 144-154.

28. Pinheiro A, Teixeira M, Rego L, Marques F, Henrique N, et al (2005) Genetic and morphological variation of Solea lascaris (Risso, 1810) along the Portuguese coast. Fish Res 73: 67-78.

29. Chaklader R, Siddik M, Nahar A (2015) Taxonomic diversity of paradise threadfin Polynemus paradiseus (Linnaeus, 1758) inhabiting southern coastal rivers in Bangladesh. Sains Malaysiana 44: 1241-1248.

30. Vatandoust $\mathrm{S}$, Mousavi-Sabet $\mathrm{H}$, Razeghi-Mansour $\mathrm{M}$, AnvariFar $\mathrm{H}$, Heidar A, et al. (2015) Morphometric variation of the endangered Caspian lamprey, Caspiomyzon wagneri (Pisces: Petromyzontidae), from migrating stocks of two rivers along the southern Caspian Sea. Zool Stud 27: 54-56.

31. Swain P, Ridell B, Murray C (1991) Morphological differences between hatchery 
Citation: Siddik M, Chaklader M, Hanif M, Islam M, Sharker M, et al. (2016) Stock Identification of Critically Endangered Olive Barb, Puntius sarana (Hamilton, 1822) with Emphasis on Management Implications. J Aquac Res Development. 7: 411. doi:10.4172/2155-9546.1000411

and wild populations of coho salmon (Oncorhynchus kisutch): environmental versus genetic origin. Can J Fish Aquat Sci 48: 1783-1791.

32. Schreck B, Moyle B (1990) Methods for Fish Biolog. American Fisheries Society, Bethesda.

33. Kurata H (1975) Environmental conditions, in "Feeding and growth of larval fish" (ed. By the Japanese Society of Fisheries), Koseishakoseikaku Tokyo.
34. Turan C, Erguden D, Gurlek M, Basusta N, Turan F, et al. (2004) Morphometric structuring of the anchovy (Engraulis encrasicolus L.) in the black, Aegean and Northeastern Mediterranean seas. Turk J Vet Anim Sci 28: 865-871.

35. Hossain M, Nahiduzzaman M, Saha D, Khanam M, Alam M (2010) Landmarkbased morphometric and meristic variations of the endangered carp, Kalibaus Labeo calbasu, from stocks of two isolated rivers, the Jamuna and Halda and a hatchery. Zool Stud 49: 556-563. 